Marianne Løken holds a PhD in science education at the University of Oslo. Her research interest is on gender issues in science education with a particular focus on narratives of females choosing science subjects in higher education, where females are underrepresented. Løken is trained in social anthropology, special needs eduacation, communication studies and science education.

Siri $\varnothing$ ysleb $\emptyset$ S $\varnothing$ rensen, PhD, is associate professor at Department of Interdiciplinary studies of culture at NTNU. Her research concerns gender and gender equality measures, and she is in particular interested in mechanisms and processes of inclusion. Currently she works on an action research project aiming at enhancing gender balance amongst professors and research directors at NTNU.

\title{
MARIANNE LØKEN
}

University of Oslo, Norway

loken.marianne@gmail.com

\section{SIRI $\varnothing$ YSLEB $\varnothing ~ S \varnothing R E N S E N$}

NTNU - Norwegian University of Science and Technology, Norway

\section{Materielle praksiser og erfaringer "kick back". En sosiomateriell analyse av beretninger om utdanningsvalg}

\begin{abstract}
The article examines gender and recruitment for mathematics and science through a close reading of four women's stories about choosing a mathematics and science education, retrieved from a more comprehensive study of educational choice. Personal interest for the subject is an established understanding of what influence the educational choice. Strategies and campaigns for recruiting women for mathematics and science have thus been geared to awaken precisely women's interest as women In this article, we move away from an understanding of gender as a background variable to explain "interest in mathematics and science", and instead show how educational choice can be understood as socio-material practices. In the interaction between human and material actors there is also bodily experiences, something which gives gender active significance (agency). Thus, the article contributes to an extended understanding of the components that are included in educational choice and how these components relate to one another, which in turn provides new opportunities for understanding how educational choices can beaffected through material experiences and practices.
\end{abstract}




\section{INNLEDNING}

På tross av tiår med strategier for å utjevne kjønnsforskjeller i utdanningsvalg er det fortsatt mannsdominans i realfagene (NOU 2012: 15). De fleste forsøk på å forstå gjenstridigheten i det kjønnsdelte utdanningsmønstret retter enten blikket mot ekskluderingsmekanismer eller mot det individuelle valget, og forklarer kjønnsubalanse med kjønnede interesseforskjeller eller kjønnede holdninger til realfag (Adolfsson, Benckert \& Wiberg 2011; Bjørkholm, 2010). Kjønnede holdninger og interesseforskjeller, på sin side, forstås enten som iboende eller de har henvisning til samfunn og kultur (Regan \& De Witt, 2015).

I denne artikkelen vil vi utfordre de etablerte måtene å tenke om kjønnsforskjell i utdanningsvalg på. Vi utforsker hvordan vi kan forstå unge kvinners atypiske utdanningsvalg med utgangspunkt i fire historier, som er skrevet av kvinner som har valgt realfag med sterk underrepresentasjon av kvinner. Hvilke erfaringer og praksiser forstår de selv som relevante for formingen av eget utdanningsvalg? Dernest følger vi opp dette empiriske forskningsspørsmålet med et analytisk spørsmål om hvordan vi best kan forstå valghistoriene. Ved å aktivere et sosiomaterielt perspektiv i analysen av fortellingene om utdanningsvalg vil vi vise hvordan materielle og kroppslige erfaringer inngår i det å velge realfag. Artikkelen bidrar dermed til å utdype forståelsen for hvordan "personlige utdanningsvalg", kan forstås - og potensielt påvirkes.

Personlig faginteresse blir ofte beskrevet som den mest tungtveiende faktoren i studier av utdanningsvalg i Norge, som i Skandinavia, som i store deler av Europa og i øvrige land vi sammenligner oss med (Jensen \& Henriksen, 2015). Dette gjenspeiles visuelt i rekrutteringskampanjer, i retorikken som brukes i informasjonsmateriell, så vel som i det utdanningspolitiske feltet og i undervisningen. Valg av utdanning som et interessevalg er med andre ord en del av diskursen om utdanningsvalg, og kan sies å danne et dominerende narrativ (Sinnes \& Løken, 2012; Løken, 2015). Videre viser forskning på rekruttering til realfagene at interesser, valg og deltakelse i realfag henger tett sammen med identitetsarbeid (Holmegaard, Ulriksen \& Madsen, 2014; Hazari, Sonnert, Sadler \& Shanahan, 2010; Schreiner \& Sjøberg, 2007).

Samspillet mellom faginteresse og identitetsarbeid er særlig forstått som relevant i et kjønnsperspektiv, og både rekrutteringskampanjer og teknologi har vært utformet med eksplisitte konnotasjoner til femininitet med et formål om å "selge" budskapet eller produktet til kvinner (Lagesen, 2003; Lie, 2003). En systematisk gjennomgang av eksisterende kunnskap om effekter av styringsvirkemidler for å påvirke utdanningsvalg har imidlertid konkludert med at det er vanskelig å isolere tiltak for å øke andelen kvinner i realfag (Damvad, 2015). Rapporten Piger i Science, Technology, Engineering and Mathematics (STEM) viste dessuten at bildet av nordiske kvinners deltakelse i realfag har vært relativt stabilt i flere tiår - at «...der hverken har været udtalte stigende eller faldende tendenser i forholdet mellom mænd og kvinder over de siste ti år, når STEM-uddannelserne betraktes under ét.» (Damvad, 2016: 6), og at «Der hersker imidlertid også en utbredt misforståelse af, at udviklingen går den rigtige vej, i takt med at flere kvinder tager lændervarende uddanelser.» (ibid: 11). Dette er funn som støttes av andre utredninger, statistiske framskrivninger og forskning på valg og deltakelse i realfagene (Se for eksempel Henriksen, Dillon \& Ryder, 2015).

Når kjønnede utdanningsvalg og kjønnede rekrutteringskampanjer ser ut til å ha en begrenset effekt i form av å skape endring i praksis og meningsproduksjon, så ser vi det som et argument for hvor viktig det er å utforske nye perspektiver på utdanningsvalg. Posthumanistiske teorier åpner nettopp for perspektiver som hittil i liten grad har vært anvendt for å forstå utdanningsvalg. Disse teoriene går bort fra å tenke på menneskelig aktørskap som det viktigste å forstå i studier av samfunn og praksiser. Tvert imot vektlegges betydningen av materialitet og av samspillet mellom menneskelige og ikkemenneskelige aktører. I denne artikkelen drøfter vi derfor sosiomaterielle perspektiver i analysen av utdanningsvalg. 


\section{FRA ET SOSIOKULTURELT TIL ET SOSIOMATERIELT PERSPEKTIV PÅ UTDANNINGSVALG OG KJФNN}

Mye realfagdidaktisk forskning på utdanningsvalg har fokus på menneskelig samspill og dialog som de viktigste former for læringsprosesser. En slik inngang har røtter i en sosiokulturell tilnærming til fagfeltet, hvor det menneskelige subjekt er i fokus. Et sosiokulturelt perspektiv er primært opptatt av interaksjonen mellom mennesker, og artefakter forstås først og fremst som medierende redskap og ikke som noe med aktiv agens (Lenz Taguchi, 2012). Sosiomaterielle innganger vektlegger imidlertid relasjoner som etableres mellom menneskelige og ikke-menneskelige aktører (Serder, 2015).

Innenfor posthumanistiske teorier brukes samlebetegnelsen materialitet om ikke-menneskelige aktører. Litt forenklet inkluderer det alt fra teknologier, maskiner, artefakter, dyr, tekster, objekter, kropper, naturfenomener til materielle praksiser (se for eksempel Barad, 2007; Solbrække, 2011; Alaimo \& Hekman, 2008). Menneskelige handlinger forstås som gjensidig betinget av de materielle og de sosiale sammenhengene handlingen inngår i (Lenz Taguchi, 2012), eller som Tobias Roehl (2012) uttrykker det: «Human actors and material objects are closely interwoven and transform each other in socio-material practice.» (Roehl 2012: 110). En eksplisitt bevissthet om det materielles betydning for sosialt liv skal ikke forstås som at «ting» har agens i kraft av seg selv. En bok eller en båt «lever» ikke, men det kan være en forbindelse mellom mennesket og det materielle som «gjør» noe - de intra-agerer. I denne intra-aksjonen oppstår agens, sagt med begrepene til fysikeren Karen Barad. Barad, som bygger videre på arbeidene til Judith Butler, Michael Foucault, Bruno Latour og Donna Haraway (Hekman, 2010). Barad skriver følgende om intra-aksjon og agens:

«Agential intra-actions are specific causal material enactments that may or may not involve "humans. "Indeed, it is through such practices that the differential boundaries between "humans" and "nonhumans," "culture" and "nature," the "social" and the "scientific" are constituted. (...). Reality is not composed of things-in-themselves or things behind-phenomena but "things"-in-phenomena. The world is intra-activity in its differential mattering. It is through specific intra-actions that a differential sense of being is enacted in the ongoing ebb and flow of agency. That is, it is through specific intra-actions that phenomena come to matter-in both senses of the word.» (2003: 817).

Med andre ord brukes begrepet intra-aksjon for å poengtere materialitetens virke, og agens er altså ikke noe folk eller ting har, men noe som oppstår i intra-aksjon mellom mennesket og materialitet. Med en sosiomateriell inngang rettes altså oppmerksomheten mot det som oppstår i møtet, i intraaksjonen, mellom materialitet og det menneskelige subjekt. Tanken er at det oppstår noe i denne sammenvevingen som får en virkning $i$ seg selv: Vi kan tenke oss utdanningsvalg som effekter av en slik sammenveving. Med dette utfordres også en forståelse av utdanningsvalg som primært kognitive, rasjonelle prosesser. Utdanningsvalg forstått som sosiomateriell intra-aksjon anerkjenner og inkluderer også den situerte kroppen og kroppen som levd erfaring. I en empirisk studie vil dette innebære at vi må være observante for beskrivelser av materielle erfaringer og praksiser - beskrivelser av betydningsfulle ting, sanseopplevelser - i tillegg til mellommenneskelig samhandling, til sosial interaksjon.

I et sosiomaterielt perspektiv på utdanning ligger altså en erkjennelse av at det materielle inngår $i$ valget. Slik vi snart skal se, utgjør for eksempel tilgang til naturvitenskapelige bøker og leker i oppveksten en del av en materiell erfaring, som forstås som en komponent i utdanningsvalget. I de empiriske analysene er det altså et poeng å ikke tolke beskrivelser av materielle erfaringer og praksiser som representasjoner eller uttrykk for subjektive interesser. Poenget er snarere å bruke nettopp intraaksjon som analysegrep for å undersøke hva som produseres i disse erfaringene og praksisene. I neste omgang gir dette en mulighet for å synliggjøre og dekonstruere komponentene som inngår som produktive (positive) komponenter i utdanningsvalget. 
Forståelsen av hvordan kjønn spiller en rolle i utdanningsvalg, endrer seg også når vi anlegger et sosiomaterielt perspektiv. Kjønn blir ikke lenger et distribusjonsmønster av egenskaper, en bakgrunnsvariabel eller en biologisk eller kulturelt betinget identitetskategori. Kjønn blir noe som produseres, noe som gjøres i sosiomaterielle relasjoner og som oppstår i intra-aksjoner. Donna Haraway har formulert det slik: "Gender is a verb. Not a noun. Gender is always about the production of subjects in relation to other subjects, and in relation to artifacts.» (Haraway, 2004: 329).

Det åpne spørsmålet som ble stilt innledningsvis, om hvilke erfaringer og praksiser kvinner som har valgt en realfagsutdanning forstår som relevante for formingen av eget utdanningsvalg, kan med et sosiomaterielt perspektiv og forståelsen av utdanningsvalg som "intra-agens" utdypes til en todelt problemstilling: (1) Hvordan inngår materielle erfaringer og praksiser i beretningene om utdanningsvalg, og hva oppstår i disse erfaringene? (2) Hvordan inngår kjønn som materialitet i utdanningsvalget (intra-agensen)?

\section{DET EMPIRISKE DATAGRUNNLAGET OG METODOLOGI}

Analysen baserer seg på kvalitative data, nærmere bestemt individuelle beretninger om utdanningsvalg som er samlet inn over en treårsperiode, fra 2009 til 2012, av førsteforfatteren av denne artikkelen. Beretningene ble skrevet av jenter som fylte mellom 18 og 22 år i 2009, og som begynte på et høyere studium i realfag med lav kvinneandel høsten 2008 eller 2009. Invitasjonen til å delta i studien ble publisert på en nettside, og lenken ble sendt til norske universiteter og høgskoler der kvinner var underrepresentert på realfaglige studier. Nettsiden inneholdt blant annet følgende tekst:

Hvem er du? Hva eller hvem har inspirert og motivert deg til å velge matematikk, fysikk, kjemi, informatikk, geofag, ingeniør- eller sivilingeniørutdanning? Er det spesiell opplevelser, erfaringer, personer eller annet som har hatt betydning for studievalget ditt? Hva tenker du om å være en av få jenter på studieprogrammet du har valgt? Hvilke forventninger har du til tiden som student? Hva skal til for at du fullfører studiet? Hva kan få deg til å avslutte studiene, bytte studieprogram og/eller studiested? Og hva tenker du om dine fremtidige yrkes- og karrieremuligheter? Vi håper du griper sjansen til å skrive ned din historier. Med dette ønsker vi å beskrive, forstå og forklare hvorfor enkelte jenter velger fag som de fleste jenter velger bort. Skriv fritt i den formen som passer deg! Det er fint om du reflekterer over spørsmålene over, men du bestemmer selv hva du vil skrive om.

I tillegg inneholdt nettsiden informasjon om utvalgskriterier, regler for deltakelse, informasjon om anvendelse av historiene - og informasjon om samtykke og anonymitet. Både på nettsiden og i oppfølgingsintervjuene på e-post, ble det understreket at forskningsprosjektet gjennomføres i tråd med retningslinjer fra Norsk senter for forskningsdata, NSD.

Det kom til sammen inn 17 beretninger høsten 2009. Umiddelbart etter fristen for innsending av historiene ble historiene lest grundig og det gjort en skriftlig oppsummering av de innsendte tekstene før beretningene ble lagt inn i analyseprogrammet NVivo, for å systematisere og kategorisere data. Ved hjelp av NVivo har det vært mulig å sette sammen og utlede meningsfulle kategorier fra de store tekstmengdene. Dette har vært et godt utgangspunkt for videre fortolkning og narrative analyser.

Informantene ble fulgt opp med oppfølgingsintervju på e-post våren 2011 og våren 2012. I de to oppfølgingsintervjuene ble informantene bedt om å reflektere over hvordan de forholder seg til fortellinger om jenter og/i realfag, om rekrutteringstiltak som «jentepoeng» har hatt noen betydning, om forventningene og studieplanene har endret seg underveis, hvilke råd de vil gi til andre unge kvinner som ønsker å studere det samme, hvorfor de tror så få jenter velger å studere matematikktunge fag som fysikk, informatikk og ingeniørfag, hva de tenker om kjønnede interesse- og utdanningsvalg, og mer generelt om hvilke erfaringer de har gjort seg som unge kvinner i et mannsdominert studiemiljø. 
Spørsmålene som ble stilt i invitasjonen om å delta høsten i 2009, og senere gjennom oppfølgingsintervjuene, hadde til hensikt å undersøke ulike historier bak jentenes valg om å studere et mannsdominert realfag, ofte omtalt som utradisjonelle eller utypiske valg i forskningslitteraturen. Hensikten har vært å åpne opp for dialog og deltakelse gjennom utformingen av spørsmålene. Historiene skal forstås som deler av informantenes livshistorier - deres livsverden og levde liv satt i spill gjennom beretningene (Dauite \& Lightfoot, 2004).

Det etiske utgangspunktet er at lesing av tekst alltid begynner med en helhetlig forståelse og antakelse, uansett hvor man er i forskningsprosessen, og at forståelsesprosessen skrider fremover under lesing og nylesing av materialet (Horsdal, 2012; Tracy, 2010). De narrative analysene har foregått i flere faser, og beveget seg frem og tilbake i ulike stadier av prosessen. De ulike analysefasene har tatt for seg likheter og forskjeller i materialet - og mønstre og tendenser på tvers av beregningene. Videre har vi undersøkt hvordan innholdet i beretningene samsvarer og bryter med annen forskning på utdanningsvalg. Vi har særlig sett etter hvordan informantene forhandler identitet og kjønn, knyttet til erfaringer og praksiser. På bakgrunn av våre fortolkninger av materialet har vi så laget fortettede portretter av fire informanter, som vi mener belyser og gir innhold til denne artikkelens problemstilling.

I denne artikkelen går vi altså i dybden på fire av totalt 17 narrativer, fordi disse fire på forskjellig vis illustrerer utdanningsvalg som sosiomaterielle konstruksjoner - eller praksiser. Vi møter «Lone» som studerer bygg og miljøteknikk, «Vanja» som studerer materialteknikk, «Kate» som studerer marin teknikk, og «Mona» som studerer teknisk kybernetikk ved norske universitet og høgskoler i den perioden dataene samles inn. Personnavn og stedsnavn i utdragene er endret av hensyn til anonymitet. De er alle underrepresentert på sine studieprogrammer. Utover det har de ulike erfaringer, forventninger og fremtidsdrømmer. Det er de materielle erfaringene og praksisene som vi leser ut av de fire narrativene, som er i fokus. Hensikten er ikke å generalisere fra fire historier til hele materialet - heller ikke til en større del av populasjonen unge kvinner som velger realfag. De empiriske utdragene som er gjengitt i denne artikkelen, gir ingen fullstendig gjengivelse av materialet, men er utdrag og bidrag som er valgt ut for å belyse artikkelens problemstillinger. Med en sosiomateriell inngang har hensikten vært å åpne opp for ulike forståelser, heller enn å representere og generalisere fra et empirisk datamateriale. Denne innsikten kan brukes videre til å reflektere over implikasjoner ved bruk av en sosiomateriell inngang til studier av utdanningsvalg.

\section{FiRE BERETNINGER OM UTDANNINGSVALG SOM KJфNNEDE OG MATERIELLE PRAKSISER}

I litteraturen om utdanningsvalg finnes det forskningsresultater som antyder at jenter føler seg fremmedgjorte i møte med realfag, men også at dette er forestillinger som kan utfordres (Løken, 2015). Løken (2015) viser blant annet hvordan kjente forestillinger om jenter/i og realfag kan utfordres av jenter som velger atypisk. Det betyr ikke at disse jentene ikke føler seg fremmedgjorte overfor måter realfag beskrives og oppfattes på. Den nevnte artikkelen viser hvordan informantene i studien har et tvetydig og ambivalent forhold til sitt eget utdanningsvalg (ibid). De bekjenner seg til mange av stereotypiene som eksisterer innenfor faget, samtidig som de utfordrer disse gjennom sine historier - og valg.

De fire narrativene som er gjenstand for vår analyse i denne artikkelen, viser også at etablerte bilder av jenter i/og realfag kan utfordres, at kvinnelige utdanningsvelgere er forskjellige, og at de har ulike aspirasjoner og begrunnelser for hvorfor de har valgt som de har valgt. Beretningene preges av ambivalens og tvetydighet og gir lite grunnlag for generaliseringer. Informantene har ulike opplevelser med realfag i oppveksten, foreldrenes rolle beskrives ulikt, skoleerfaringene varierer, karakterene varierer - og mange opplever at de ikke passer inn i den historien som fortelles om kvinner i/og realfagene (ibid). Startpunktet for analysen som presenteres i det følgende, er altså en antakelse om at tradisjonelle måter å tenke kjønnsforskjell i utdanningsvalg bør utfordres. Beretningene fra kvinnene 
i studien leses dermed ikke som uttrykk for noe "typisk kvinnelig", men som uttrykk for betydningen av materialitet i disse kvinnenes utdanningsvalg. Beretningene har noen fellesnevnere som sier noe om betydningen av materialitet. Informantene er blant annet opptatt av å jobbe med noe praktisk, og nevner dette som en viktig årsak til utdanningsvalget de har gjort. Og med «praktisk» mener de konkrete oppgaver, som flere omtaler som alt annet enn «kontorarbeid». Kontoret symboliserer noe upraktisk og som det motsatte av kroppsarbeid, et fysisk rom som hemmer opplevelsen av fleksibilitet, og som oppleves som ufritt. Enkelte understreker at de «alltid har elsket realfag», mens andre skriver at studievalget var mer eller mindre tilfeldig. Men uansett beskrives det å jobbe med noe praktisk som viktig, slik Kate gjør i sin beretning:

«Hvis jeg ikke hadde valgt NTNU, ville det kanskje vært søppelmann eller salmaker, og droppet hele denne lange utdanningen, og jobbet med kroppen istedet...[...]...Som søppelmann kan man stå opp tidlig og dermed legge seg på stranden. Man bruker kroppen...[...]...Angående salmaker har jeg alltid likt hest, og liker lukten av lær, da kunne man også brukt sine kunstneriske evner...[...]... Jeg kunne også tenke meg å tatt videreutdanning, enten en doktorgrad ved NTNU eller et annet universitet, kanskje i utlandet, eller et fagbrev som kan relateres, f.eks. rørlegger eller sveiser, maskinmann eller lignende...»

Kates beretning skiller seg ut fra en forestilling om at kvinner er fremmedgjorte for realfag i kraft av å vokse opp med andre aktiviteter enn gutter. Kates beretning er særlig interessant i et sosiomaterielt perspektiv fordi det får frem betydningen av kropp og materialitet i hennes historie. Hun beskriver videre hvordan skogen hun vokste opp med, tomta, traktoren og sagingen utgjør en vesentlig del av hennes erfaringer, noe hun så setter i forbindelse med senere utdanningsvalg. Dette er også noe hun reflekterer over i lys av forestillinger om hva som er typiske yrker for kvinner - som betyr at vi også velger utdanning og yrke ut fra hva vi oppfatter som passende for vårt kjønn (se for eksempel NOU 2012:15; Solbrække, 2011). Dette er refleksjoner som går igjen i datamaterialet. De unge kvinnene skriver om erfaringer som kan knyttes til det materielle og kroppen, enten det er snakk om identitet, feminine og maskuline idealer eller erfaringer med kroppens muligheter og begrensninger. Dette vil vi belyse nærmere med utgangspunkt i de fire narrativene, som vi analyser i denne artikkelen.

\section{BETYDNINGER AV TING OG TINGENES BETYDNING}

Artikkelens første empiriske forskningsspørsmål er å undersøke hvilken betydning «tingene» har for utdanningsvalg: Hvilken rolle spiller materielle erfaringer? Ofte beskrives unge kvinners interesse for realfag ut fra et ønske om å redde verden eller med andre mer eller mindre idealistiske fortegn (Bøe, 2012). Et uttalt ønske om å utgjøre en positiv forskjell er også til stede i datamaterialet i denne studien. Samtidig er budskapet tvetydig, og enkelte vektlegger det materielle fremfor det ideologiske som betydningsfullt. Informantene beretter gjerne om erfaringer og praksiser med materielt innhold, når de ønsker å trekke frem ting av betydning for at de fattet interesse for realfag i tidlig alder. Vanja er en av flere som detaljert beskriver hvilken betydning realfaglige ting og artefakter, bøker og filmer har hatt for henne:

«Ellers husker jeg at mamma og pappa kjøpte sånne faktabøker til oss. Jeg husker kanskje spesielt bøkene om dyr, om værfenomenene på jorda, og om verdensrommet. Jeg synes verdensrommet er kjempekult enda. På barneskolen hadde jeg en periode der jeg lærte meg masse stjernebilder, og så var Men in Black favorittfilmen min. Og så synes jeg det alltid har vært spennende med sånne faktaserier på tv om verdensrommet og gode gamle Globus 2.»

Innenfor et sosiokulturelt perspektiv kan dette utdraget tolkes slik: Fordi foreldrene kjøpte faktabøker i barndommen, ble det skapt en interesse hos datteren som førte til en fascinasjon av verdensrommet, som igjen ledet til et valg om å studere realfag. Med en sosiomateriell inngang vektlegger vi 
i stedet tilstedeværelsen av og tilgangen til bøkene og betydningen av vitenskap i populærkulturen. Og at det kan skapes forbindelser mellom det materielle og det menneskelige subjektet på andre måter, dersom vi ikke utelukkende ser på forbindelsen som uttrykk for foreldrenes intensjoner og sosioøkonomiske bakgrunn, men som viktige sosiomaterielle forbindelser. Ved at Vanja trekker inn faktabøker og science fiction-film i fortellingen om bakgrunnen for utdanningsvalget, ligger det også en mulighet for at det nettopp er i intra-agens, i møtet med vitenskapelige artefakter som produserer kimer til det som senere blir et utdanningsvalg. Samtidig advarer Barad mot «tingliggjøring» fordi materialitet er mer enn fysiske gjenstander i våre omgivelser (Barad, 2003). I sosiokulturelle teorier fremstår som nevnt tingene som redskap for menneskelig handling, mens en sosiomateriell inngang vektlegger hvordan tingenes nærvær og tilgjengelighet er avgjørende for hva vi kan foreta oss - og hvordan (Pickering, 1995). Ting og praksis kan derfor tolkes som to sider av samme sak, og Kates barndomsdrøm illustrerer dette.

Kates barndomsdrøm var å lage racerbåter. Båter og maritime erfaringer er en stor del av det materielle repertoaret hun vokste opp med:

«Lillebror og jeg har hatt en liten båt sammen siden vi var små så strandliv, øyliv og båtliv ble det mye av. Fritidsbåt har nok vært hovedfokus, og det er kanskje derfor jeg hele tiden har hatt en liten hemmelig drøm om å lage racerbåter.»

Båtene og det maritime fortsetter å spille en rolle i videregående opplæring. Kate forteller blant annet om et forskningsprosjekt i tredje klasse på videregående der de skulle bygge en fjernstyrt båt:

«Vi ville lage fjernstyrt båt, og kontaktet institutt for marin teknikk.» Studiestedet arbeidet med et prosjekt der elever fra videregående skulle inkluderes $i$ arbeidet med å lage fjernstyrte båter «og konkurrere med hverandre i havnebassenget...[....]...Vi fikk komme på besøk, lage små båter og fikk masse informasjon, utstyr, miniforelesning, omvisning og et kompendium i marin intro som vi kranglet om å besitte.»

Vi tolker det materielle, for eksempel kompendiet de «kranglet om å besitte» og de materielle erfaringene med å lage fjernstyrte båter, som sosiomaterielle intra-agenser. Og selv om hun midtveis i sin beretning likevel er i tvil om lidenskapen for båter var avgjørende for hennes valg, avslutter hun med å si at «Barndomsdrømmen er å lage racerbåter...», et eventuelt valg som vil involvere et aktivt materielt agentskap - en sammenfletting av kunnskap og utøvelse, teknologi, verktøy og fysiske objekter for å materialisere og virkeliggjøre drømmen.

Mens Kates beretning viste hvordan familien og skolen var arenaer for materielle erfaringer og praksiser som inngår i prosessen med å velge utdanning, så kan teknologi i barndommen også materialiseres gjennom et bredere oppvekstmiljø. Mona vokste opp i industriby og gikk i hjørnestenfabrikkens bedriftsbarnehage. Fabrikken lagde blant annet raketter som de hørte om i barnehagen. Med en sosiomateriell inngang kan slike erfaringer og praksiser forstås som et eksempel på intra-aksjon mellom mennesket og det materielle:

«En stor påvirkning har vært stedet jeg kommer fra og familien min. For på hjemstedet mitt jobber det veldig mange sivilingeniører innen de store teknologibedriftene...........Disse bedriftene spesialiserte seg innen våpensystemer, marinteknologi, forsvarsteknologi, offshoreteknologi, gassturbiner, bildelindustri, olje- og gassindustrien og flyindustrien...[...]...Og disse bedriftene merkes også godt $i$ lokalsamfunnet ved at de sponser idrettslag, kulturinnslag og arrangementer, og de donerer teknologiske hjelpemidler til skolene og de arrangerer ulike familiedager, åpne dager og skoleturer der man fär se hva bedriftene holder på med. Og opp gjennom årene har jeg vært på mange slike dager og siden mange i familien min jobber $i$ noen av disse bedriftene har jeg fätt et innblikk i teknologi de utvikler - og dette har alltid interessert 
meg. Helt fra da vi i barnehagen hørte om rakettene de lagde og opp gjennom skolegangen min har jeg ofte fătt høre om den spennende teknologien de holder på med.»

Utdraget over viser blant annet hvordan materielle erfaringer og praksiser har vært tydelig til stede i oppveksten, og gjennom måten hun konstruerer sin beretning på, inngår de i Monas utdanningsvalg. De materielle erfaringene hun beskriver, sier noe om betydningen av å være en deltakende aktør i et miljø med et omfattende teknologisk repertoar. De ulike teknologiene hun beskriver i utdraget over, forutsetter kunnskap om bruk og anvendelse. Derfor er teknologi en kombinasjon av gjenstander, praksis og kunnskap, som Mona møter på ulike arenaer i oppveksten. Teksten viser hvordan teknologien hun vokste opp med, har formet hennes identitetsarbeid og påvirket hennes valg om å studere teknologifag. Dette defineres ofte som et maskulint fag i litteraturen, hvor feminint og maskulint settes opp mot hverandre (Lie, 2003). Løsningen som ofte gis, er å rekonstruere teknologi som feminin for at kvinner skal føle seg hjemme i fagene (ibid). Donna Haraway (1991) tar et oppgjør med en slik forståelse, og understreker hvordan teknologien har blitt en del av livene våre, slik den helt opplagt spiller en helt sentral rolle i Monas fortid, nåtid og fremtid. Ved å undersøke hvordan det menneskelige intra-agerer med teknologier, dekonstruerer vi også tilknytningen mellom teknologi og maskulinitet. Vi ser på dette feltet som en del av subjektets levde erfaring i et større perspektiv, uten at vi tviholder på kulturelle dikotomier som beskrevet over (ibid). Slike kulturelle dikotomier og stereotypier vil vi komme tilbake til under.

\section{MENNESKEKROPPEN I BERETNINGER OM UTDANNINGSVALG}

Artikkelens andre forskningsspørsmål handler om hvordan vi kan inkludere en analyse av kroppens materielle betydning for utdanningsvalg. Og som beskrevet innledningsvis, kobles ofte kjønn og interesse sammen gjennom identitetsarbeid i sosiokulturelle perspektiver på utdanningsvalg og kjønn. I beretningene som analyseres i denne artikkelen, tematiseres kjønn noen ganger som en sentral dimensjon, andre ganger som noe mindre sentralt. Uansett kan vi ikke være i verden uten kropp - og kroppen har betydning for våre valg. Kroppslig situering forstås altså som en del av utdanningsvalget, og med kroppen tenkt som intra-agens i utdanningsvalget gjøres kjønn. (Haraway 2004). I mange tilfeller kommer kjønn til uttrykk i fortellingene når det er snakk om kropp og kroppslige erfaringer eller egenskaper, men aller tydeligst kommer det frem når beretningen dreier seg eksplisitt om identitetsarbeid. Dette er noe Vanja reflekterer over i tilknytning til kjønnede forventninger og positiv særbehandling i et forsøk på å rekruttere flere jenter til realfag:

«Jeg har kanskje litt guttejente i meg, selv omjeg vil si at jeg er en del jente-jente også. Påstanden om at jenter ikke klarer det samme som gutter provoserte meg veldig mye da jeg var yngre, og jeg husker jeg var ganske sinna på kjønnskvotering en stund, siden det på en måte var en slags innrømmelse om at jenter er dårligere....[...]....Men jeg husker at jeg tok gutteandelen med $i$ betraktning da jeg lurte på om jeg skulle velge elektro i stedet for kjemi, selv om det i veldig liten grad hadde vært et avgjørende element.»

Vanjas historie er preget av tvetydighet og ambivalens til eget valg - og eget kjønn, forstått som identitetskategori. Det blir også tydelig at kjønn og identitetskonstruksjon er komplisert. Hun skriver blant annet at hun er «litt forvirret i forhold til hvordan jeg skal forholde meg til mitt eget kjønn...». Dette er et tema hun tar opp igjen i oppfølgingsintervjuet høsten 2011. Her utdyper hun hvordan det er å være kvinne i et mannsdominert miljø, og hvordan dette har påvirket egne valg. Vanja er opptatt av at vi ikke setter hverandre i bås, og «...synes det blir teit når folk begynner å forklare oppførselen min ut i fra hvilket kjønn jeg er.» Hun vil ikke reduseres «til et nummer», som vil si å bli «redusert til hvilket kjønn» hun er. Kanskje er det derfor hun er så opptatt av å ta avstand fra det stereotypiske feminine, og beskriver seg selv som en guttejente som liker «tekniske ting», men «kanskje på en litt annen måte enn guttene.» Dette forklarer hun med at gutter og jenter har ulike erfaringer med tekniske ting: 
«...det føles som om guttene liksom alltid kan litt mer, og at jeg ikke har fät med meg like mye fordi jeg er vokst opp som jente. Så jeg blir interessert på jentemåten, kanskje? Jeg kan ikke masse om biler eller programmering fra før, liksom. Jeg fär $i$ hvert fall en følelse av at vi gjennomsnittlig stiller med litt ulikt utgangspunkt...».

Flere av informantene reflekterer over ulike former for kjønnet forskjellsbehandling, ulike muligheter og ulik tilgjengelighet til objekter og teknologi i oppveksten. Dette er refleksjoner som er interessante å lese med en sosiomateriell inngang, da de åpner opp for å tenke nytt om betydningen av å skape muligheter og handlingsrom i skole og fritid, på tvers av og på tross av kjønn. Fremfor å anta at kjønn er noe individer "har", og som styrer utdanningsinteresser og valg, så kan vi spørre hvordan kjønn gjøres som en som kroppslig intra-agens.

Diskusjoner om betydningen av identitet, feminine og maskuline verdier, mestringsopplevelser og interesser er hyppig diskutert i forskningslitteraturen, men sjelden i tilknytning til kropp. En sosiomateriell inngang gir kroppen en mer fremtredende plass i analysene av unge kvinners beretninger om utdanningsvalg. Kroppen som åsted for materielle erfaringer og praksiser knyttes, i et posthumanistisk perspektiv, ikke først og fremst til påvirkning av rasjonelle beslutninger og kognisjon, men snarere til affekt og emosjoner. Om vi tar Barads posisjon som utgangspunkt, så forstås det å vite og å tenke som materielle praksiser, som intra-aksjoner. På samme måte kan vi tenke om følelser. De inngår i sosiomaterialitet og kan dermed fortolkes som noe "mer" enn individuelle psykologiske trekk. Kroppslig situering og følelser er intra-agens og inngår i utdanningsvalget som noe produktivt, som i Lones historie. Lone har alltid fått høre at dersom hun har gode nok karakterer, kunne hun velge akkurat hvilken utdanning hun ville - på øverste hylle. Hun fikk høre at dette ville sikre henne en god jobb og en god økonomi. Hun valgte å studere til sivilingeniør. Men hun beskriver veien fram som tøff:

«...veien hit til første året har vært lang og hard. Mest en kamp mot lærere og skolesystemet. En vei jeg i dag ikke ville gått igjen.»

Lone skriver at hun «valgte bygg fordi jeg er sta og liker å bevise at andre har feil.» Når Lone forteller om opplevelser fra barnetrinnet, bruker hun sterke og følelsesladede ord. Det er helt tydelig at hun har erfaringer som har satt spor, og som har blitt en sentral del av hennes valghistorie:

«I min barneskoleklasse var det hierarki, og min klasseforstander hadde ikke vanskelig med å favorisere toppen av dette hierarkiet. Jeg var en av dem på bunnen, jeg hatet skolen og klassen min. Det var mange dager jeg kom hjem fra skolen, sint og gråtende. Dette fordi klasseforstanderen min ikke var noen god lærer. Denne læreren underviste meg i norsk og engelsk. Og i disse fagene fikkjeg ingenting til, ordene ble aldri de samme som de andres når jeg skulle skrive dem ned, og høytlesning var et mareritt. I frykt for at klassen skulle le, memorerte jeg teksten som skulle leses høyt.»

I sitatet ser vi hvordan ord som beskriver følelser- hat, sinne, gråt og frykt - er fremtredende i Lones fortelling. Disse vonde følelsene forbindes med en lærer, skolesituasjonen og bestemte fag som ikke er realfagene. Ordet «frykt» går også igjen ellers i Lones fortelling. Begrepet knyttes til frykten for å feile, til å mislykkes, miste ansikt og lignende. Denne frykten handler også om å ikke passe inn. Bestevenninnen på barnetrinnet «ble frarådet å være på samme gruppe...[...]...Hun var flink $i$ alt. Jeg var bare god i matte. Men det var det ingen som brydde seg om».

Åpningen på Lones historie er dyster, og bygger seg opp til et vendepunkt i Lones unge liv. Dette vendepunktet skjer i forbindelse med et konferansemøte i 7. klasse: 
«Det hele toppet seg da min lærer greide og si til meg og min mor på konferansemøte i 7. klasse at jeg ville ende opp som vaskedame, og ville ikke få en utdanning fordi jeg ikke var rask nok oppe i hodet til det.»

Lone forteller at hun gråt hele veien hjem mens hun sa til sin mor:

«Jeg var ikke dum. Jeg skulle få en god jobb, hvertfall en som var bedre betalt enn lærerne, og hvertfall en som var bedre ansett en dem. Så skulle jeg sende et brev når jeg er ferdig der jeg kunne si «DU TOK FEIL, JEG ER IKKE DUM.»

Lone formidler tydelig frykten for å bli oppfattet som dum. Hun trekker frem denne erfaringen som viktig for sitt senere utdanningsvalg. Samlet sett viser fortellingen til Lone tydelig hvordan følelser er en sosiomateriell praksis. Motivasjonen for utdanningsvalget knyttes til en følelse av å ville bevise noe overfor andre, og kanskje også overfor seg selv. Fremtidsvisjonene i historien materialiseres gjennom brevet hun vil skrive til læreren. Brevet kan derfor tolkes som en betydningsfull artefakt i beretningen.

På ungdomstrinnet kommer et nytt vendepunkt i Lones liv. Hun jobber mye med fagene, men ikke med matte og naturfag, som hun anser som enkelt «...det var logisk, fulgte regler og var ikke noe problem». Det var norsken og engelsken hun slet med, men hun klare å skjule dette overfor sine klassekamerater:

«På ungdomsskolen var matte og naturfag mer verdsatt enn på barneskolen. Og at jeg var en av trinnets beste i matte, fikk ingen til å mistanke at jeg ikke leste bøkene i norsken, men lånte dem på biblioteket på lydbok. Min frykt for å bli tatt for å være dum, overdøvde alt.»

Også skolehverdagen på ungdomstrinnet var preget av uro og frykt. Men så kommer vendepunktet. Læreren fikk mistanke om at noe ikke var som det skulle, og sendte Lone til pedagogisk-psykologisk tjeneste:

«Der ble jeg møtt av en mann som var hyggelig og hørte på alt det jeg hadde å si. Jeg var ikke dum. Etter mange tester så det ut som det egentlig ikke var noe problem, jeg kunne de mest brukte grammatikkreglene og bøye ord var ikke noe problem, dem hadde jeg jo pugget. Men så kom der en test hvor alt gikk galt, og igjen fikk jeg følelsen av å være dum. Men PP-mannen syntes dette var ytterst interessant. Dette endte opp med at jeg fikk diagnosen dysleksi.»

Lone fikk diagnosen dysleksi. Dette opplever hun som en stor lettelse:

«Alle var sjokkerte. Ingen i klassen min trodde på meg når jeg sa det. De sa «du som er så flink kan ikke ha dysleksi». Men det hadde jeg. Dette ga meg en ro. Jeg var ikke dum. Mine vanskeligheter med å lese og skrive hadde en årsak. Dette gjorde at jeg kunne senke skuldrene litt.»

Historien viser hvordan dysleksi kan sette begrensninger for materielle praksiser og erfaringer, men også at selve diagnosen kan være en positiv opplevelse. Lone er den eneste av jentene i datamaterialet som beskriver sin historie som dyslektiker i tilknytning til utdanningsvalget. Men historien er særlig interessant fordi den så tydelig formidler hvilke muligheter og begrensninger den materielle kroppen har. I et sosiomaterielt perspektiv mener vi dysleksi som diagnose kan forstås som en del av kroppens materialitet, og som dermed inngår i utdanningsvalget gjennom identitetsarbeid.

I studien beskriver informantene seg selv som mer eller mindre frie, selvstendige velgere som til syvende og sist handler i tråd med sine faglige interesser, og motivasjonen kan tolkes innenfor rammene av en slik tanke om disiplinering. Ved å «ukjønne» kroppen, fremheve den som kjønnsnøytral i sine beskrivelser, ta avstand fra symboler og identitetsmarkører som assosieres med det kvinne- 
lige og feminine, beskrive seg som «gutte-jenter» som «alltid» har vært interesserte i realfag, tar de kontroll over kroppen, slik at det å være/ha en kvinnekropp ikke skal komme i konflikt med deres (utdannings)valg. Kanskje kan vi tolke dette som at de unge kvinnene distanserer seg fra kulturelle forestillinger om kvinner ved å ta avstand fra disse gjennom å velge seg en utdanning med maskuline idealer. Slik kan de skape seg et rom av muligheter til å praktisere utenfor de kulturelle, stereotype kjønnsdiskursene. I Lones historie blir det veldig tydelig at den kjønnede kroppen trer i bakgrunn, og i forgrunnen fortelles en historie om hvordan diagnosen dysleksi har preget hennes deltakelse og påvirket hennes valg. Informanten må forholde seg til kroppen som setter rammer og grenser for den individuelle valgfriheten.

Uansett hva vi begrunner våre valg med, er mennesket dypt forankret i den materielle verden. Og det materielle gir muligheter og setter begrensninger for individet, for utdanningsinstitusjonene og for politikkutformerne. Avslutningsvis vil vi drøfte noen mulige implikasjoner ved en sosiomateriell, teoretisk inngang.

\section{IMPLIKASJONER AV EN SOSIOMATERIELL INNGANG TIL REALFAGDIDAKTISK FORSKNING}

Hensikten med artikkelen har vært å vise at et sosiomaterielt perspektiv kan bidra til å utvide forståelsen av hvordan utdanningsvalg formes. Gjennom en empirisk undersøkelse av hvordan kvinner som har valgt å studere realfag i et mannsdominert felt, og hvordan de selv forteller sine valghistorier, har vi sett hvordan et sosiomaterielt perspektiv og Karen Barads (2007) begrep om intra-agens kan brukes for forstå hvordan materielle erfaringer og praksiser inngår i utdanningsvalg. Vi har med dette også vist hvordan kjønn inngår som noe som gjøres i intra-agens, og som inngår i utdanningsvalget. Fremfor å redusere utdanningsvalg til intensjonelle interessevalg eller til kognitive, rasjonelle prosesser, har vi vist at materielle former for agens er i virksomhet når kvinner som har valgt realfag, forteller.

Beretningene viser hvordan kroppslige, sanselige erfaringer og intra-agens med bestemte ting blir forstått som viktige komponenter i formingen av et ønske eller en beslutning om å studere realfag. Tingene som omgir oss, og opplevelsene vi har med dem, og vår kroppslige situering i verden er med på å forme valget om å studere realfag. Dette perspektivet gir også en inngang til å tenke om kjønn som noe som produseres i intra-agens, fremfor som noe strukturelt eller sosialt som styrer utdannningsvalg.

Mennesket har verken forrang eller er den eneste bærer av handlekraft eller agens i en sosiomateriell tilnærming. Eller som Anne-Jorun Berg skriver i artikkelen «Hva skjedde med Kyborgen?»: «Vi er alle en del av verden med hele dens innhold på alle plan, fra det minste molekyl til det største hav og høyeste fjell og ut i universets stjernehimmel.» (Berg, 2014: 121). I et sosiomaterielt perspektiv innebærer dette at det materielle har en naturlig og likeverdig plass på linje med det menneskelige subjekt i analyser av komplekse sosiale prosesser og praksiser - som utdanningsvalg. Det er med andre ord når vi inkluderer alt som har betydning for subjektets valg og deltakelse, at vi kan snakke om en sosiomateriell inngang til realfagdidaktisk forskning. Ifølge Lens Taguchi gjør en sosiomateriell inngang til læring oss i stand til å skape et språk som bedre kan beskrive det materielles betydning i tilknytning til læring, fordi en slik tilnærming innebærer å nyttegjøre seg av forskjeller, mangfold og kompleksitet i forhold til læring (Lenz Taguchi, 2012). Dette mener vi har stor overføringsverdi til studier av utdanningsvalg. Det vil si at det å lære - eller å velge utdanning - blir et kroppslig og materielt spørsmål på linje med et spørsmål om tenking og forståelse med utgangspunkt i språk og diskurs (ibid.). Dette er perspektiver som utfordrer ideer om konsekvenser av materielle former for agency, eller agens (Barad, 1998). I en diskurs om utdanningsvalg kan dette forstås som at det materielle vi omgis av, inngår i valget - og at subjektet er i en kontinuerlig, konstituerende prosess (Braidotti, 1994), slik 
informantene i denne studien beskrev som et kontinuerlig identitetsarbeid - tett sammenvevd med det materielle i omgivelsene gjennom de tre årene følgestudien varte.

\section{KONKLUSJON: FRA SIGNIFIKANTE ANDRE TIL SIGNIFIKANTE ANNET}

Denne artikkelen kan leses som et argument for og en illustrasjon på hvordan utanningsvalg kan forsås som sosiomateriell intra-agens (Barad, 2007). Denne forståelsen både utfordrer og supplerer de mer tradisjonelle sosiokulturelle tilnærmingene til utdanningsvalg, der utdanningsvalget forstås som et individuelt interessevalg som formes i sosiale omgivelser. Hovedforskjellen på den sosiokulturelle og den sosiomaterielle tilnærmingen er hvordan det menneskelige subjektet forstås og posisjoneres. En sosiomateriell analyse innebærer at den menneskelige subjekt ikke lenger står i sentrum for analysen.

Den eksisterende forskningslitteraturen har identifisert "signifikante andre", for eksempel lærere, familie, venner og såkalte rollemodeller, og vist hvordan de er betydningsfulle for utdanningsvalg (Danielsson, 2013; Sjaastad, 2011). I denne artikkelen har vi vist hvordan materielle erfaringer og praksiser er av betydning for utdanningsvalg, og vi betegner dette som "signifikant annet". Påstanden vår, avslutningsvis, blir dermed at "signifikant annet" må tas inn i analyser av utdanningsvalg på lik linje med "signifikante andre": Dersom vi ønsker å finne nye måter å påvirke utdanningsvalg på, har vi mye å tjene på å utdype forståelsen av hvordan materielle praksiser og erfaringer "kicks back", sagt med Karen Barads posthumanistiske terminologi.

\section{REFERANSER}

Adolfsson, L., Benckert, S. \& Wiberg, M. (2011) Gapet har minskat: skillnader mellan hög- och lågpresterande flickors och pojkars attityder till biologi, fysik och kemi 1995 och 2007 i NorDiNa 7(1): 3-16

Alaimo S. \& S. Hekman (2008). Material Feminism. Bloomington \& Indianapolis: Indiana University press.

Barad, K. (2003). Posthumanist Performativity: Toward an Understanding of How Matter Comes to Matter. Signs: Journal of Women in Culture and Society, 28(3), 801-831.

Barad, K. (2007). Meeting the Universe Halfway. Quantum physics and the entanglement of matter and meaning. Durham \& London: Duke University Press.

Berg, A-J. (2014) Hva skjedde med Kyborgen? Tidsskrift for kjønnsforskning. 02/2014, s.110-126.

Björkholm, E. (2010) Technology Education in Elementary School: Boys'and Girls 'Interests and Attitudes i NorDiNa 6(1) : 33-42

Braidotti, R. (1994). Nomadic subjects. Embodiment and sexual difference in contemporary feminist theory. New York: Columbia University Press.

Butler, J. (1990). Gender trouble. Feminism and the subversion of identity. London: Routledge.

Bøe, M. V. (2012). What's in it for me? Norwegin students' choices of post-compulsory science in an expectancy-value perspective. Doktorgradsavhandling, Universitetet i Oslo.

Dauite, C. \& Lightfoot, C. (2004). Narrative Analysis. Studying the development of individuals in society. Thousand Oaks: Sage.

Damvad Analytics (2016). Piger i Science, Technology, Engineering and Mathematics (STEM). Kortlægning af utfordringer inden for køn, ligestilling og udannelse i Norden. Rapport 18/o1/16.

Damvad Analytics (2015). Styringsvirkemidler som påvirker utdanningsvalg. Kunnskapsoppsumering og analyse. Rapport 02/06/15.

Danielsson, A.T. (2013). Science for whom? Case studies of two male primary school student teachers' construction of themselves as teachers of science in NORDINA 9(2): 145-155.

Haraway, D. (1991). Simians, cyborgs, and women: The reinvention of nature. London: Free Associations Books.

Haraway, D. (2004).Modest_Witness@Second_Millenium. The Haraway Reader (s. 223- 
250). New York/London: Routledge.

Hazari, Z., Sonnert, G., Sadler, P. M., \& Shanahan, M. C. (2010). Connecting high school physics experiences, outcome expectations, physics identity, and physics career choice: A gender study. Journal of Research in Science Teaching, 47(8), 978-1003.

Hekman, S. (2010). The material of knowledge. Feminist disclosures. Bloomington / Indiana: Indiana University Press.

Henriksen, E., Dillon, J. \& Ryder J. (2015). Understanding Student Participation and Choice in Science and Technology Education. New York/London: Springer Dordrecht Heidelberg.

Holmegaard, H. T., Ulriksen, L. M., \& Madsen, L. M. (2014). The process of choosing what To study: A longitudinal study of upper secondary students' identity work when choosing higher education. Scandinavian Journal of Educational Research, 58(1), 21-40.

Horsdal, M. (2012). Telling lives: Exploring dimensions of narratives. New York: Routledge.

Jensen, F. \& Henriksen, E.K. (2015). Short stories of educational choice - in the words of science and technology students, In Ellen Karoline Henriksen; Justin Dillon \& Jim Ryder (ed.), Understanding student participation and choice in science and technology education. Springer. ISBN 97894-007-7792-7. Kapittel 9. s 135 - 151

Latour, B. (2005) Reassembling the social: An introduction to actor-network theory. Oxford:

Oxford University Press.

Lagesen, V. (2005). Fra firkanter til rundinger? produksjon av feministisk teknologipolitikk i

en kampanje for å rekruttere jenter til datastudier. Kvinneforskning. Nr. 1/2005.

Lenz Taguchi, H. (2012). Pedagogisk documentation som aktiv agent: Introduktion til intraaktiv pedagogic. Malmö: Gleerups.

Lie, M. (2003). He, she and IT revisited. New perspectives on gender in the Information Society. Oslo: Gyldendal Akademisk.

Lykke, N. (2012). Feminist studies. A guide to intersectional theory, methodology and writing. New York: Routledge.

Løken, M. (2015). When Research Challenges Gender Stereotypes: Exploring Narratives of Girls' Educational Choices, In Ellen Karoline Henriksen; Justin Dillon \& Jim Ryder (ed.), Understanding student participation and choice in science and technology education. Springer. ISBN 978-94o07-7792-7. Kapittel 17. s. 277- 295.

NOU 2012:15 (2015). Politikk for likestilling. Oslo: Departementenes servicesenter. Pickering, A. (1995). The mangle of practice: Time, agency, and science. Chicago: University of Chicago Press.

Regan, E. \& De Witt, J. (2015). Attitudes, Interest and Factors Influencing STEM Enrolment Behaviour: An Owerview of Relevant Literature, in Henriksen, E. K., Dillon, J. and Ryder, J. (ed.), Understanding Student Participation and Choice in Science and Technology Education. Springer. ISBN 978-94-007-7792-7. Kapittel 5. s. 63-88.

Roehl, T. (2012). Disassembling the classroom - and ethnographic approach to the materiality of education. Ethnography and Education, 7(1), 109-126.

Schreiner, C. \& Sjøberg, S. (2007). Science education and youth's identity construction - two incompatible projects? In D. Corrigan, J. Dillon and R. Gunstone (Eds.), The re-emergence of values in science education (pp. 231-247). Rotterdam: Sense Publishers.

Serder, M. (2015). Möten med PISA. Kunskapsmätning som samspel mellan elever och provuppgifter $i$ och om naturvetenskap. Malmö: Malmö Høgskola.

Sinnes, A. \& M. Løken (2012). Gendered education in a gendered world: looking beyond cosmetic solutions to the gender gap in science. Cultural Studies of Science Education, 1(1), s. xx-xx. Springer.

Sjaastad, J. (2011). Sources of inspiration: The role of significant persons in young people's choice of science in higher education. International Journal of Science Education, 33, 1-22.

Solbrække, K. N. (2011). Maskulin (u)orden i norsk sykepleieutdanning. I Leseth, A. og

Solbrække, K. N. (red.), Profesjon, kjønn og etnisitet. (s. 35-55). Latvia: Cappelen Damm AS.

Tracy, S. J. (2010). Qualitative quality: Eight "big-tent" criteria for excellent qualitative research. Qualitative Inquiry, 16(10), 837-851. 